\title{
Trends in Gender Inequalities in Life Expectancies at Birth in Africa, 1950- 2015
}

\author{
William Muhwava ${ }^{1}$ and Gideon Rutaremwa ${ }^{2}$ \\ ${ }^{1}$ Chief of Population and Youth Section, Economic Commission for Africa, \\ Addis Ababa, Ethiopia \\ wmuhawava@uneca.org. \\ ${ }^{2}$ Population Affairs Officer, Economic Commission for Africa, \\ Addis Ababa, Ethiopia
}

\begin{abstract}
In this paper, life expectancies by gender are presented for countries and regions in Africa. The gender gaps in life expectancy are calculated. Data on life expectancies by sex for African countries are available from the UNDESA and the latest estimates of 2015 are used. Four patterns of gender gap in life expectancy at birth trends are observed in Africa. The first group have high life expectancies and large gender gaps and comprises of mainly small islands (Seychelles, Mauritius and Mayotte) and those in North Africa whole life expectancy at birth has exceeded 70 years. The second group are those countries where the gap has been stable but narrowed during the peak of the AIDS epidemic but has started widening in recent times and comprising countries mainly in Southern Africa. Group 3 are those countries where the gender gaps has been low over the period and have narrowed or remained consistently low in recent times, mainly in West Africa. The last group comprises of countries where life expectancy at birth for males exceeds that of females. Currently, Swaziland and Mali are the only countries exhibiting this pattern. Thus, some few countries in Africa have followed trends that have been experienced by developed countries and many have followed a different pattern.
\end{abstract}

Key words: Inequality, gender gap, life expectancy at birth, Life table.

\section{Introduction}

In demography, it is a widely established fact that in most human populations, life expectancy at birth for females is higher than that of males and the gap between sexes. Over the development course, the trends in life expectancies for males and females have increased at different paces. One of the pioneers in this field, Weihl documented in 1938 the increasing ratio in male to female mortality rates. Her methods and findings on the subject has inspired demographers to work on the issue. A public health specialist, Sowder noted in 1954 that although the deaths rates for both males and females had been declining over time, the rates of female mortality were declining more rapidly than the rates for males.

The disparities between female and male life expectancies at birth were noted earlier on and were incorporated in the development of Model Life tables by Coale and Demeny (1966). All subsequent model life tables have incorporated the differential life expectancies between males and females in their computations. However, although the gender gap in life expectancies in favor of females phenomenon has occurred in all populations during the course of history, there are a few exceptions that have been noted in Africa. Life expectancy has increased significantly in Africa, particularly in the past ten years as communicable diseases have been controlled.

Also, improvements in healthcare for children and better access to medicines. Malaria control and the availability of drugs for HIV have made a significant contribution. Africa is, by far, the region of the world with the highest level of mortality. Overall life expectancy at birth for both sexes as of 2015 is estimated at 46 years, whereas in Asia, the region with the second lowest life expectancy, it is 67 years. High infant mortality still account for the low life expectancies being experienced in some African countries. Declines in infant mortality rates in Africa started to slow down considerably since the 1990s. During the last 2 decades, some African countries that have been severely affected by AIDS-related mortality, life expectancy dropped significantly during the height of the epidemic. These slow declines have meant that Africa has lagged more and more behind other regions and hence the mortality gap has widened. 
The rapid improvement in life expectancies at birth in the developed world has been accompanied by an increase in the gap between male and female survival. This widening sex difference is due mainly to the higher pace of improvement for females rather than to a decrease in life expectancy for males. However, at very high levels of development, the life expectancies for men and women tend to converge again.

Researches on gender-related health inequalities are located within two main approaches. The first seeks to understand how culture shapes gender roles and therefore health perceptions, policy and research questions and the second relies on epidemiological measurements of health status, morbidity, and mortality. In this report, the second approach seems more applicable.

\section{Objectives}

The paper aims to describe the trends in the differences in life expectancies by sex and show whether these have been increasing over time. This paper is based on the notion that all societies continue to be divided along the 'fault line' of gender, which considerably affects the survival and wellness of both men and women. Thus, this results in differential survivorship between females and males.

This research paper is crucial in demonstrating that gender gaps in life expectancies exist in Africa. The gender gap in human lifespan is profoundly affected by societal and behavioral factors and movement towards greater parity in lifestyle between men and women is a major factor in the recent reduction in gender gap in life expectancy.

\section{Literature Review}

Women generally have longer life expectancy at birth than men (Barford et al, 2006). As life expectancy has been increasing, the disparity between the two genders has also been increasing. However, the male-to-female life expectancy gender gap has varied across time and country. According to Nathanson (1984) the female advantage in life expectancy tends to be smaller among poor nations. In addition, the gender gap has not remained constant within societies over time. For example, among wealthy nations, the female advantage in life expectancy began to rise considerably during the late 1800 s and early 1900s (Pampel, 2002). However, women's relative gains in life expectancy eventually stalled and have even begun to reverse course over the past several decades due primarily to changes in smoking behavior by men and women (Pampel, 2002)

The estimation done by the United Nations (1982) using an orthogonal regression line showed that the difference between female and male life expectancy at birth in Africa, would be 2.8 years, 3.8 years, 4.7 years and 5.7 years for life expectancies at birth of 40 years, 50 years, 60 years and 70 years, respectively. Although this estimation was corrects in terms of the trends of increasing disparity, the magnitudes seems higher than what most African countries have experienced at each level of life expectancy at birth.

Some explanations have been advanced for the increasing gender gap during the course of history in life expectancies at birth. According to diverging trend can partly be explained by the declining rates in maternal mortality. However, a major element is attributable to sex differences in behavior and biology

\section{Methodology}

Trends in gender inequalities in life expectancies at birth in Africa between 1950 and 2015 will be presented. Data on life expectancies by sex for African countries are available from the United Nations Department of Economic and Social Affairs. The dearth of reliable data from censuses and vital registration is the main reason why the study had to rely on UN data. Estimates of life expectancy are calculated updated biennially by the Population Division of the UN. Original data are collected from countries from sources such as vital registration, sample registration systems, surveillance systems, censuses and demographic surveys. Such information is compiled on a regular basis.

The data are evaluated and if necessary adjustments for incompleteness are made. Life expectancies at birth is calculated directly from reported deaths and population counts, where data on deaths by age are of good quality or where reasonable adjustments for age misreporting and incompleteness can be made. However, when data are not available, life expectancies at birth are derived through indirect methods based on special questions asked in censuses and demographic surveys and the use of model life tables. The data used in this paper was released in August 2015.

Life expectancies at birth were compared over time and space. Life expectancy at birth has long been recognized as a summary measure of mortality that allows inequality levels and trends to be compared within and across societies. The life expectancy difference (LE difference) was used. Here, the purpose of the analyses was to quantify the magnitude of disparities using life expectancy at birth. The life expectancy at birth is a summary indices that expresses the magnitude of the health differences between different sections of the population. One of the main advantages of such a summary index is that it facilitates spatial and temporal comparisons. 


\section{Results}

The results in Figure I show that gender differences in mortality and life expectancy vary by region country. But in all regions of Africa, on average men live shorter lives than women.

\section{Figure 1: Trends in Life Expectancies in Africa and its Various Regions}

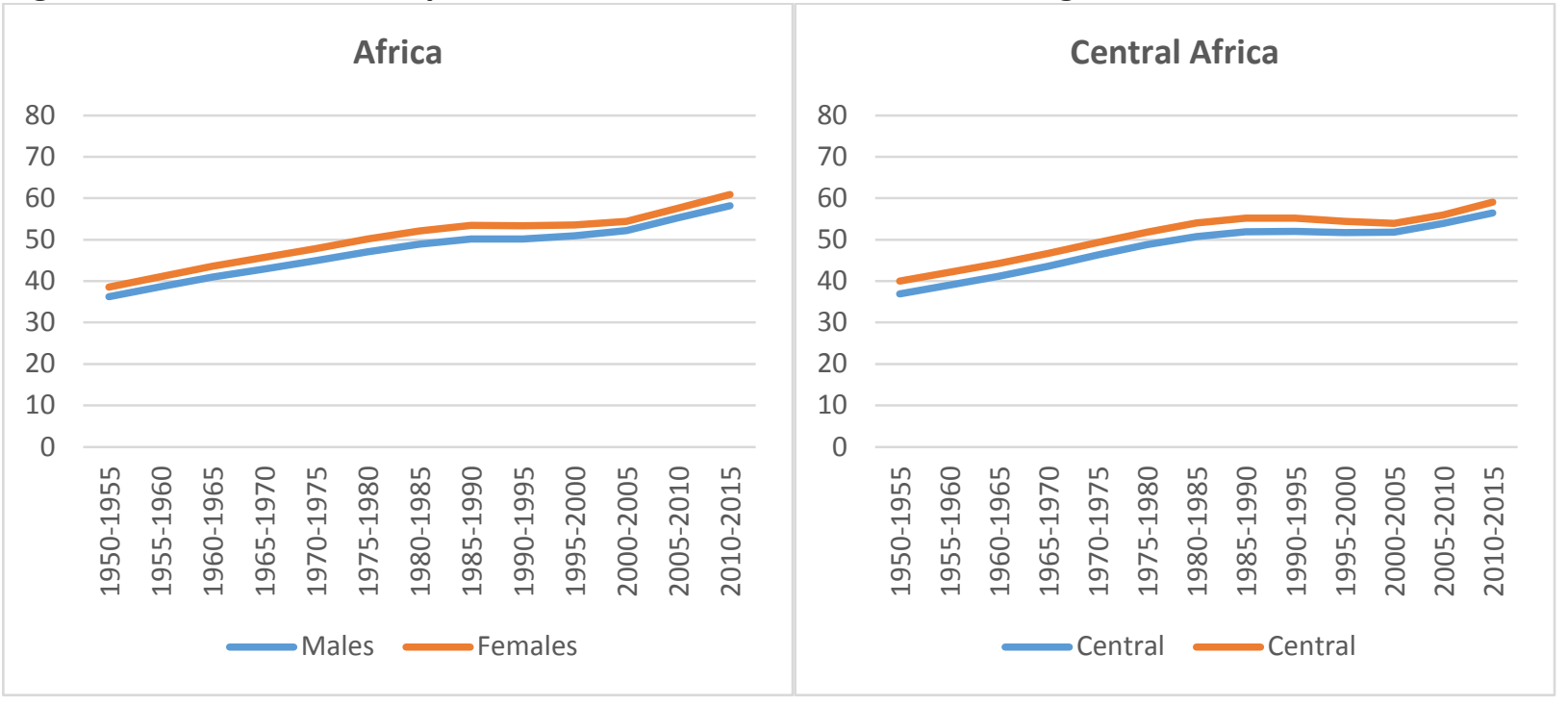

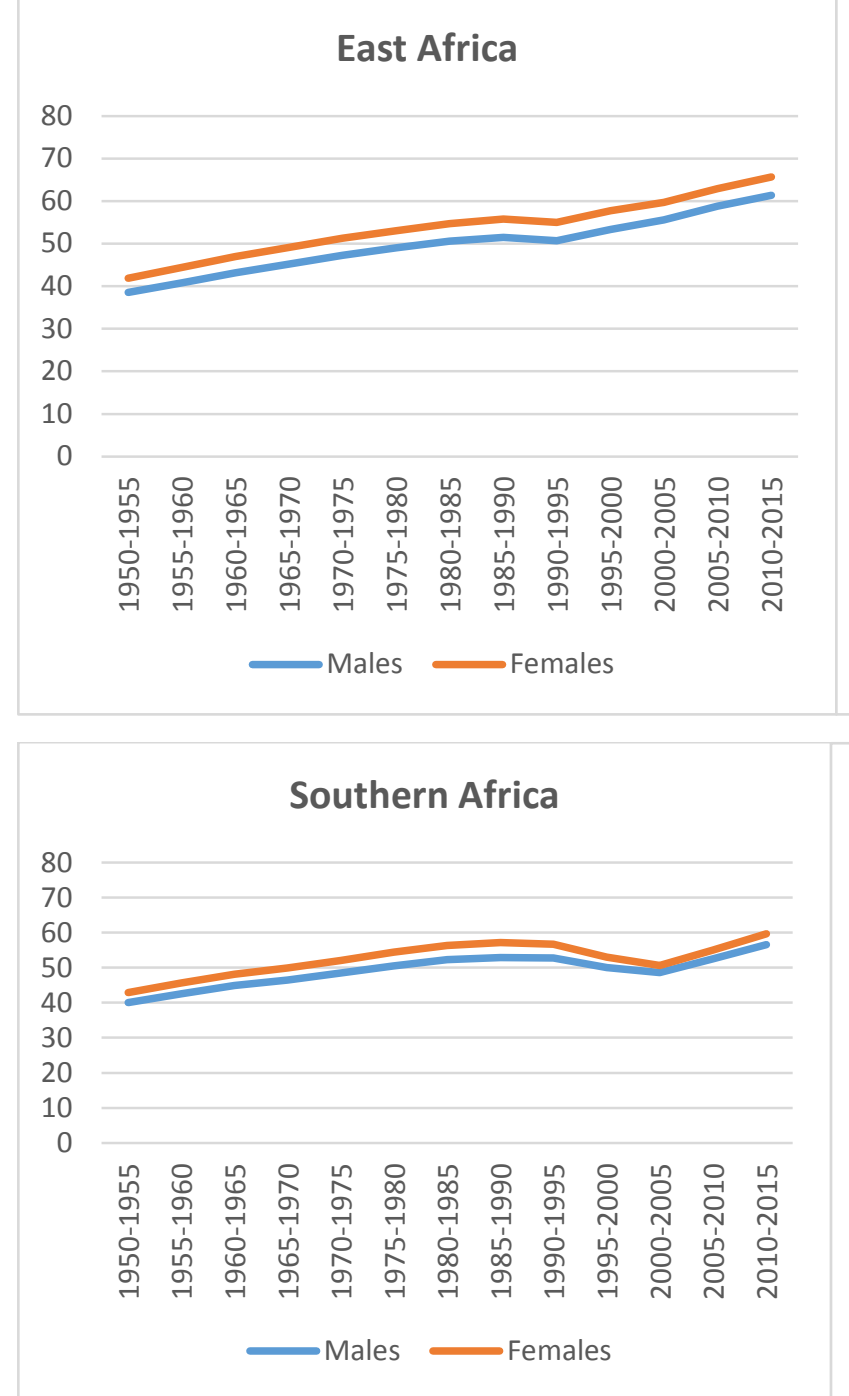

All regions in Africa have made significant progress in improving survivorship of the population.Life
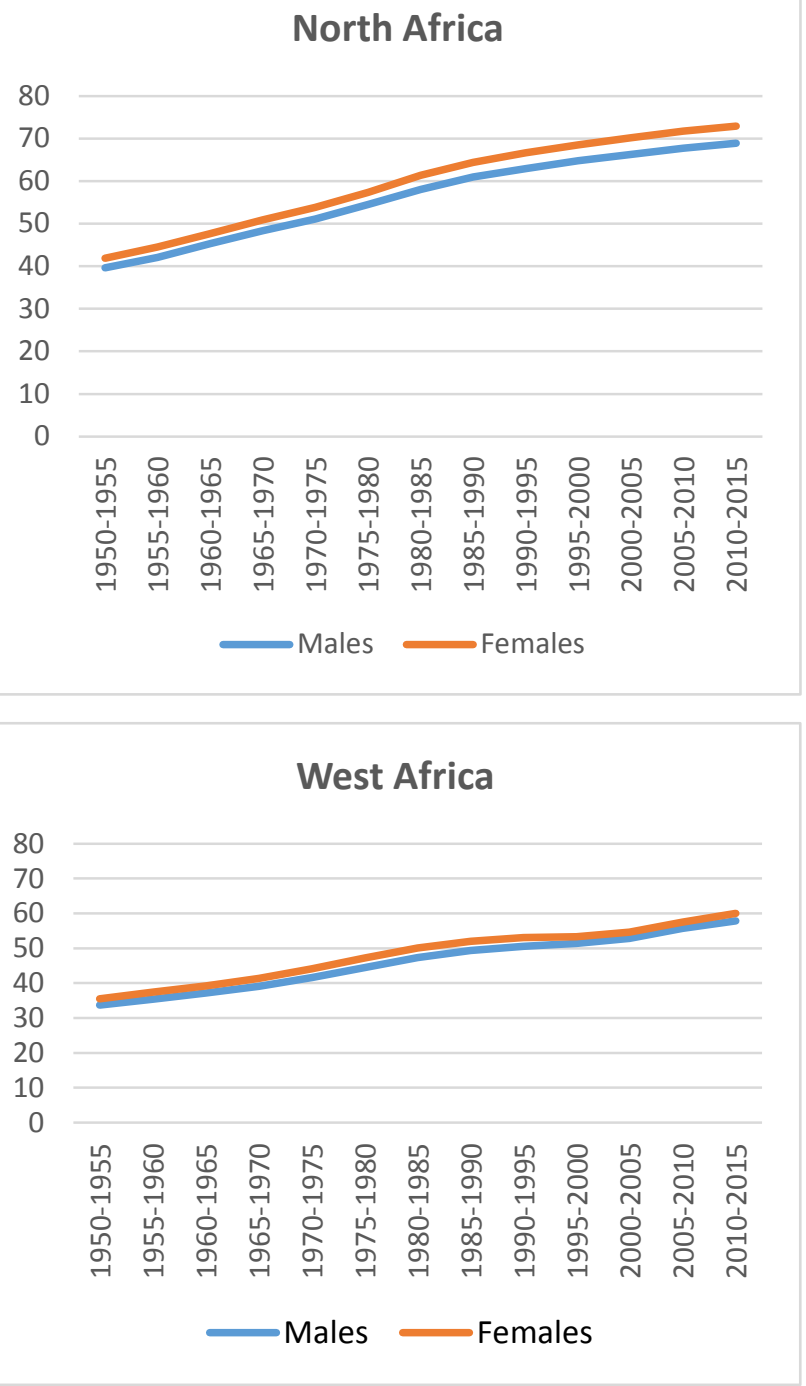

expectancy at birth for the African continent has increased from 41 years for females and 39 years for females during the period 1950-1955 to 61 years for 
females and 58 years for males during the period 20I0-20I5. For females, there was an average annual rise of 4 months of life per calendar year and for males it was 3.8 months. For all the years, the life expectancies at birth for females are higher than that for males. The disparity between male and female life expectancies has slightly increased from 2 to 3 years over the period for the whole continent. From the period 1950-1955 to 1990-1995, the gender gap in life expectancy increased moderately. However, from the period 1995-2000, the gender gap narrowed reflecting the impact of AIDS-related mortality on female survivorship in some countries. After 2005, there have been some marginal widening of the gender gap as the reversal of the impact of AIDS-related mortality.

Life expectancies at birth for two countries are show in Figure 2. Seychelles exhibits the patterns countries with high life expectancy at birth, while Central African Republic is one of the countries with the lowest.

Figure 2: Life Expectancies at Birth for Males and Females in Seychelles and Central African Republic
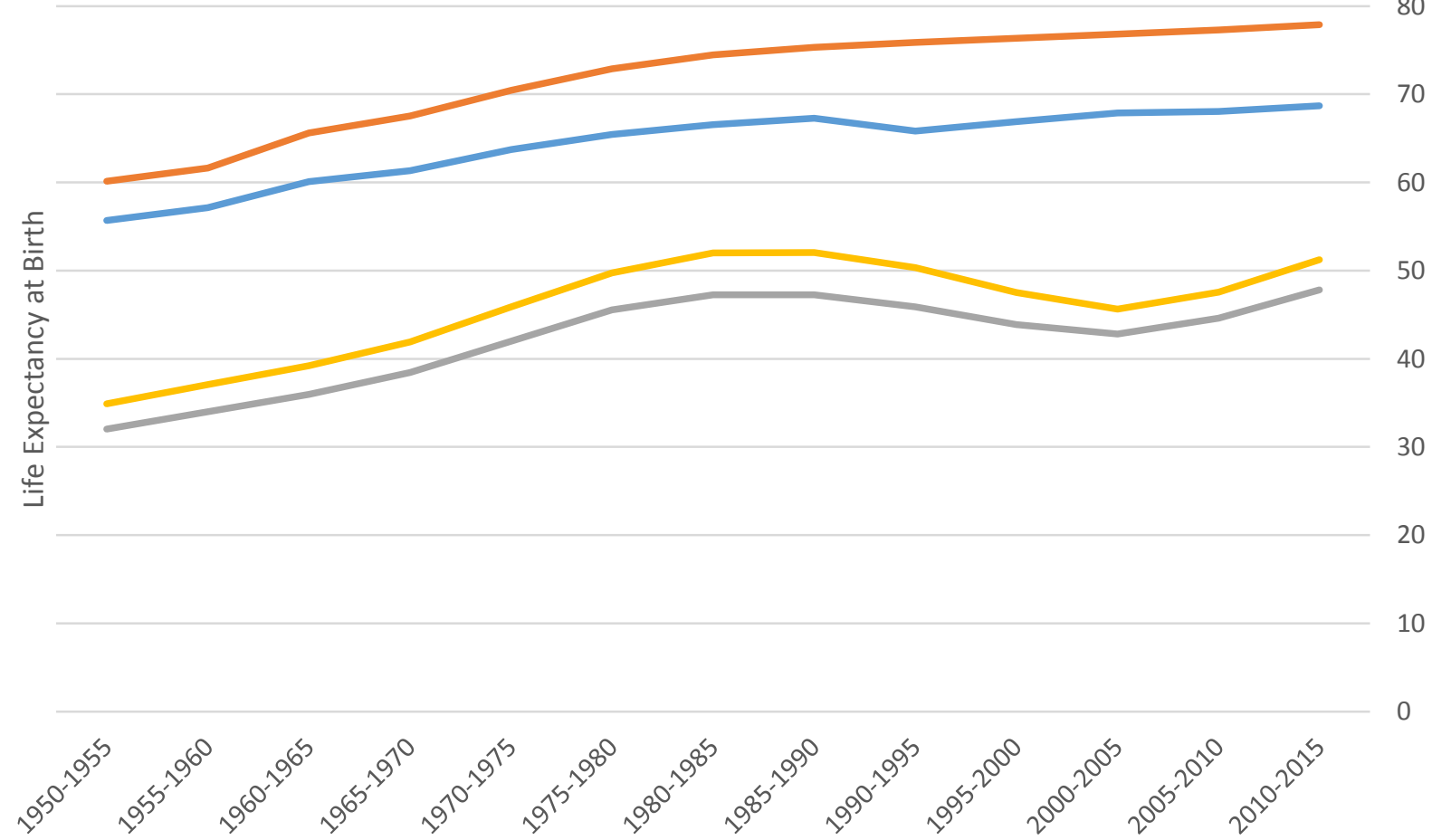

Seychelles shows a wider gender gap than Central African Republic. The gap for Seychelles has grown wider as the life expectancies at birth have been increasing for both sexes. However, in Central
African Republic which is still experiencing high mortality, especially in infancy, the gender gap has remained relatively narrow. The gender gaps for the regions of Africa are presented in Figure 3.

Figure 3: Gender Gap in Life Expectancy at Birth for the Five Regions of Africa

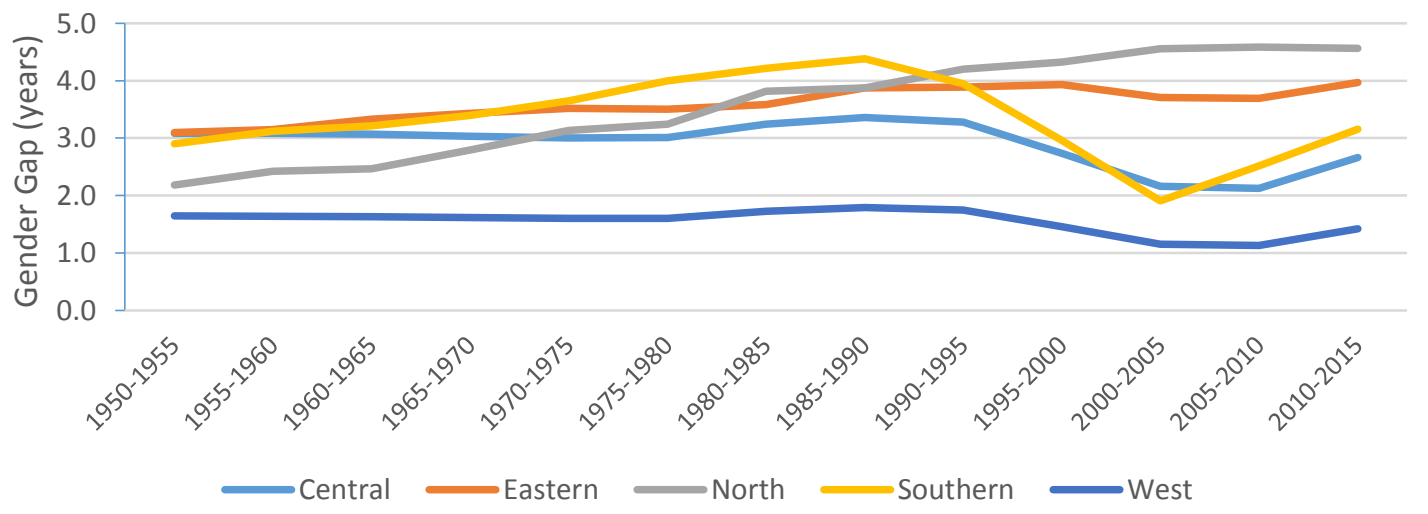


North Africa has shown a consistently increasing gender disparity in life expectancies at birth and has the highest in Africa. The gap has almost doubled from 2.2 years in 1950-1955 to 2010-2015. The gender gap for the East African region, which has the second highest gender gap in Africa, has moderately increased by I year. Southern Africa showed the fastest increase prior to 1990 and thereafter a sharp drop in the period 1990 to 2005 and an increase has been recorded in the last 10 years. Central Africa did not experience any changes during the initial phases but the gender gap started widening in the 1980s and peaked around 1995 and thereafter a moderate drop in the period 1990 to 2010 and an increase has been recorded in the last 5 years. The gender gap in West Africa has been the smallest and has remained fairly stable over the period.

In the following tables, an examination of the gender gaps of individual countries are shown. In Table I, life expectancy gender gaps in Central Africa countries during the period 1950-1955 to 2010-2015 are presented.

Table 1: Life Expectancy Gender Gap in Central Africa Countries during the period 1950-1955 to 2010-2015

\begin{tabular}{|c|c|c|c|c|c|c|c|c|c|c|c|c|c|}
\hline Country & $\begin{array}{c}1950- \\
1955\end{array}$ & $\begin{array}{c}1955- \\
1960\end{array}$ & $\begin{array}{l}1960- \\
1965\end{array}$ & $\begin{array}{l}1965- \\
1970\end{array}$ & $\begin{array}{c}1970- \\
1975\end{array}$ & $\begin{array}{l}1975- \\
1980\end{array}$ & $\begin{array}{l}1980- \\
1985\end{array}$ & $\begin{array}{c}1985- \\
1990\end{array}$ & $\begin{array}{c}1990- \\
1995\end{array}$ & $\begin{array}{l}1995- \\
2000\end{array}$ & $\begin{array}{l}2000- \\
2005\end{array}$ & $\begin{array}{c}2005- \\
2010\end{array}$ & $\begin{array}{r}2010- \\
2015\end{array}$ \\
\hline Angola & 2.88 & 2.94 & 2.99 & 3.04 & 3.08 & 3.08 & 2.93 & 3.92 & 3.86 & 2.93 & 2.75 & 2.83 & 2.97 \\
\hline Cameroon & 2.66 & 2.65 & 2.64 & 2.64 & 3.04 & 3.07 & 3.07 & 3.09 & 2.93 & 2.40 & 1.81 & 1.86 & 2.28 \\
\hline CAR & 2.88 & 3.06 & 3.24 & 3.46 & 3.87 & 4.20 & 4.76 & 4.81 & 4.47 & 3.62 & 2.80 & 2.96 & 3.42 \\
\hline Chad & 5.50 & 4.65 & 3.76 & 2.78 & 2.6 & 2.04 & 2.22 & 2.14 & 2.47 & 2.40 & 1.76 & 1.62 & 2.10 \\
\hline Congo & 1.79 & 2.27 & 2.69 & 3.06 & 2.86 & 2.85 & 2.85 & 2.98 & 2.9 & 2.28 & 2.13 & 2.33 & 2.97 \\
\hline E. Guinea & 2.98 & 3.02 & 3.04 & 3.08 & 3.05 & 3.11 & 3.23 & 3.15 & 3.21 & 2.96 & 2.46 & 2.40 & 2.70 \\
\hline Gabon & 3.09 & 3.13 & 3.16 & 3.17 & 3.18 & 3.19 & 3.2 & 3.09 & 2.72 & 1.65 & -0.03 & -0.78 & 0.92 \\
\hline $\begin{array}{l}\text { Sao Tome } \\
\& \text { Principe }\end{array}$ & 2.89 & 2.92 & 3.00 & 3.01 & 2.36 & 2.56 & 3.68 & 3.66 & 3.64 & 3.62 & 3.62 & 3.8 & 3.96 \\
\hline
\end{tabular}

The countries in Central Africa show very contrasting patterns. Sao Tome and Principe which has the highest life expectancy in the region has the largest gender gap of about 4 years during the most recent period. The pattern for Central African Republic shows increased widening of the gender gap over time and reaching a peak during the period 19851990, and thereafter the gap has been narrowing. Equatorial Guinea, Angola and Cameroon have experienced similar pattern to the Central Africa Republic. Congo has experienced some slow steady increase in the gap which increased by about 1.2 years over the period under consideration. Gabon which has moderately high life expectancy at birth has the narrowest gender gap, which is a clear sign of high female infant and child mortality. Chad shows a narrowing of the gender gap over time from 5.5 years in 1950-1955 to 2.1 years in 2010-2015. Gabon has also followed a similar pattern of diminishing gender parity in life expectancies at birth between males and females. Most strikingly, Gabon has experienced higher life expectancies at birth for males than females over the period 2000-2005 and 2005-20I0.

In Table 2, life expectancy gender gaps in East Africa countries during the period 1950-1955 to 20I0-20I5 are presented.

Table 2: Life Expectancy Gender Gap in Eastern Africa Countries during the period 1950-1955 to 2010-2015

\begin{tabular}{|c|c|c|c|c|c|c|c|c|c|c|c|c|c|}
\hline Country & $\begin{array}{r}1950 \\
1955 \\
\end{array}$ & $\begin{array}{c}1955 \\
- \\
1960 \\
\end{array}$ & $\begin{array}{c}1960 \\
- \\
1965 \\
\end{array}$ & $\begin{array}{c}1965 \\
- \\
1970 \\
\end{array}$ & $\begin{array}{c}1970 \\
- \\
1975 \\
\end{array}$ & $\begin{array}{c}1975 \\
- \\
1980 \\
\end{array}$ & $\begin{array}{c}1980 \\
- \\
1985 \\
\end{array}$ & $\begin{array}{c}1985 \\
- \\
1990 \\
\end{array}$ & $\begin{array}{c}1990 \\
- \\
1995 \\
\end{array}$ & $\begin{array}{c}1995 \\
- \\
2000 \\
\end{array}$ & $\begin{array}{c}2000 \\
- \\
2005 \\
\end{array}$ & $\begin{array}{c}2005 \\
- \\
2010 \\
\end{array}$ & $\begin{array}{c}2010 \\
- \\
2015 \\
\end{array}$ \\
\hline Burundi & 3.13 & 3.14 & 3.17 & 3.20 & 3.21 & 3.24 & 3.51 & 3.53 & 3.26 & 3.31 & 3.41 & 3.38 & 3.86 \\
\hline Comoros & 2.50 & 3.00 & 3.00 & 3.00 & 3.42 & 3.35 & 3.21 & 3.17 & 3.13 & 3.1 & 3.23 & 3.20 & 3.30 \\
\hline Djibouti & 2.66 & 2.65 & 2.64 & 2.64 & 3.01 & 3.07 & 3.09 & 3.05 & 3.25 & 3.32 & 2.93 & 2.94 & 3.20 \\
\hline Eritrea & 3.96 & 3.95 & 4.28 & 4.91 & 4.73 & 4.04 & 3.99 & 4.28 & 4.47 & 4.56 & 4.39 & 4.62 & 4.28 \\
\hline Ethiopia & 2.59 & 2.79 & 3.05 & 3.06 & 3.03 & 3.03 & 2.9 & 2.97 & 3.06 & 2.95 & 2.65 & 3.06 & 3.72 \\
\hline Kenya & 3.63 & 3.56 & 4.18 & 4.21 & 4.19 & 3.97 & 3.76 & 3.85 & 3.62 & 2.19 & 0.99 & 1.80 & 3.09 \\
\hline Madagascar & 2.03 & 1.92 & 1.91 & 1.84 & 1.88 & 1.92 & 2.07 & 2.18 & 2.60 & 2.42 & 2.45 & 2.85 & 2.98 \\
\hline Rwanda & 3.13 & 3.17 & 3.18 & 3.23 & 3.25 & 3.05 & 3.41 & 5.80 & 4.83 & 9.92 & 10.76 & 8.61 & 6.65 \\
\hline Seychelles & 4.43 & 4.53 & 5.52 & 6.2 & 6.74 & 7.47 & 7.9 & 8.06 & 10.0 & 9.48 & 8.96 & 9.22 & 9.22 \\
\hline
\end{tabular}




\begin{tabular}{|c|c|c|c|c|c|c|c|c|c|c|c|c|c|}
\hline Somalia & 2.96 & 3.02 & 3.06 & 3.07 & 3.09 & 3.08 & 3.09 & 3.07 & 3.04 & 3.14 & 3.12 & 3.15 & 3.23 \\
\hline South Sudan & 2.73 & 2.76 & 2.78 & 2.79 & 2.81 & 2.88 & 2.82 & 2.83 & 2.76 & 2.61 & 2.28 & 2.00 & 1.93 \\
\hline Uganda & 3.13 & 3.13 & 3.16 & 3.06 & 2.99 & 3.09 & 3.60 & 4.35 & 3.91 & 2.64 & 1.97 & 1.83 & 3.16 \\
\hline Tanzania & 3.34 & 3.35 & 3.39 & 3.37 & 3.36 & 3.40 & 3.25 & 3.20 & 2.54 & 1.44 & 1.09 & 1.30 & 3.00 \\
\hline
\end{tabular}

Some of the largest gender gaps in Africa are noted in East Africa. Seychelles, which has one of the highest life expectancy in Africa has a current gender gap of 9.2 years. The gender gap in Seychelles has more than doubled from 4.2 years to 9.2 years from 1950 1955 to 2010-2015. During the period 1990-1995, the gender gap in Seychelles peaked at 10 years. Rwanda which has the second highest gender gap in the region has also shown a similar trend to Seychelles although at a lower magnitude.
Burundi and Somalia have not experienced much changes and the gender gaps in these countries have remained at slightly over 3 years. . The gender gap for Eritrea has remained at about 4 years over the period. Southern Sudan is the only country in the region that has experienced the narrowing of the gender gap.

In Table 3, life expectancy gender gaps in North Africa countries during the period 1950-1955 to 2010-2015 are presented.

Table 3: Life Expectancy Gender Gap in North Africa Countries during the period 1950-1955 to 2010-2015

\begin{tabular}{|c|c|c|c|c|c|c|c|c|c|c|c|c|c|}
\hline Country & $\begin{array}{c}195 \\
0 \\
- \\
195 \\
5\end{array}$ & $\begin{array}{c}1955- \\
1960\end{array}$ & $\begin{array}{c}1960- \\
1965\end{array}$ & $\begin{array}{c}1965- \\
1970\end{array}$ & $\begin{array}{c}1970- \\
1975\end{array}$ & $\begin{array}{c}1975- \\
1980\end{array}$ & $\begin{array}{c}1980- \\
1985\end{array}$ & $\begin{array}{c}1985- \\
1990\end{array}$ & $\begin{array}{c}1990- \\
1995\end{array}$ & $\begin{array}{l}1995- \\
2000\end{array}$ & $\begin{array}{c}2000- \\
2005\end{array}$ & $\begin{array}{l}2005- \\
2010\end{array}$ & $\begin{array}{c}2010- \\
2015\end{array}$ \\
\hline Algeria & 1.25 & 1.36 & 1.49 & 1.61 & 1.74 & 1.88 & 2.93 & 2.9 & 3.2 & 2.91 & 4.13 & 4.2 & 4.70 \\
\hline Egypt & 1.04 & 2.08 & 2.74 & 3.37 & 3.66 & 4.14 & 4.53 & 4.69 & 4.79 & 4.83 & 4.77 & 4.60 & 4.34 \\
\hline Libya & 2.25 & 2.34 & 2.58 & 2.85 & 3.81 & 3.75 & 3.63 & 3.48 & 3.36 & 3.3 & 3.69 & 4.89 & 5.62 \\
\hline $\begin{array}{l}\text { Maurita } \\
\text { nia }\end{array}$ & 0.18 & 0.54 & 1.21 & 1.85 & 2.39 & 2.84 & 2.66 & 2.54 & 2.73 & 3.09 & 3.25 & 3.12 & 2.96 \\
\hline $\begin{array}{l}\text { Morocc } \\
0\end{array}$ & 3.43 & 3.45 & 1.87 & 2.00 & 2.06 & 2.13 & 3.05 & 2.98 & 3.40 & 3.26 & 2.91 & 2.51 & 2.02 \\
\hline Sudan & 2.84 & 2.84 & 2.88 & 2.88 & 2.91 & 2.95 & 2.93 & 2.93 & 3.13 & 3.58 & 3.77 & 3.46 & 3.00 \\
\hline Tunisia & 2.13 & 1.94 & 2.01 & 2.18 & 2.21 & 1.76 & 3.15 & 3.72 & 4.59 & 4.96 & 4.83 & 4.74 & 4.74 \\
\hline
\end{tabular}

As noted earlier, countries in this region have moderately high life expectancy at birth that are comparable to Latin American countries. All the countries except Mauritania and Sudan have life expectancies at birth that are over 70 years for both sexes. For all the countries, the gender gap has been increasing over time, except in Morocco, where there has been a reversal in this trend. Libya has the largest gender gap of 5.6 years in 2010-2015 and has increased from 2.3 years in 1950-1955. Algeria and
Egypt have also experienced a quadrupling of the gender gap in life expactency at birth, while in Tunisia this has doubled. The pattern for Sudan shows a modest increase over time and reaching a peak during the period 2000-2005, and then after the gap has been narrowing.

In Table 4, life expectancy gender gaps in East Africa countries during the period 1950-1955 to 20I0-20I5 are presented.

Table 4: Life Expectancy Gender Gap in Southern Africa Countries during the period 1950-1955 to 2010-2015

\begin{tabular}{|c|c|c|c|c|c|c|c|c|c|c|c|c|c|}
\hline $\begin{array}{l}\text { Countr } \\
\mathrm{y}\end{array}$ & $\begin{array}{c}1950- \\
1955\end{array}$ & $\begin{array}{c}1955- \\
1960\end{array}$ & $\begin{array}{c}1960- \\
1965\end{array}$ & $\begin{array}{c}1965- \\
1970\end{array}$ & $\begin{array}{c}1970- \\
1975\end{array}$ & $\begin{array}{c}1975- \\
1980\end{array}$ & $\begin{array}{c}1980- \\
1985\end{array}$ & $\begin{array}{c}1985- \\
1990\end{array}$ & $\begin{array}{c}1990- \\
1995\end{array}$ & $\begin{array}{c}1995- \\
2000\end{array}$ & $\begin{array}{l}2000- \\
2005\end{array}$ & $\begin{array}{l}2005- \\
2010\end{array}$ & $\begin{array}{l}2010- \\
2015\end{array}$ \\
\hline $\begin{array}{l}\text { Botswa } \\
\text { na }\end{array}$ & 3.90 & 3.75 & 3.60 & 3.50 & 3.70 & 4.00 & 4.09 & 4.08 & 3.66 & 2.31 & 1.82 & 4.13 & 4.71 \\
\hline $\begin{array}{l}\text { Lesoth } \\
\text { o }\end{array}$ & 2.63 & 2.58 & 2.56 & 2.56 & 2.49 & 2.50 & 2.60 & 2.5 & 2.91 & 1.88 & 0.13 & 0.49 & 0.40 \\
\hline Malawi & 0.90 & 1.00 & 1.20 & 1.35 & 1.48 & 1.71 & 2.12 & 2.57 & 1.93 & 0.72 & -0.12 & 1.50 & 2.12 \\
\hline $\begin{array}{l}\text { Mauriti } \\
\text { us }\end{array}$ & 2.47 & 3.66 & 3.60 & 4.27 & 5.56 & $8 . .50$ & 7.30 & 7.78 & 7.42 & 7.45 & 6.6 & 6.86 & 7.07 \\
\hline $\begin{array}{l}\text { Mozam } \\
\text { bique }\end{array}$ & 2.40 & 2.60 & 2.78 & 3.00 & 3.15 & 3.15 & 3.00 & 3.02 & 3.2 & 3.59 & 3.41 & 3.02 & 3.24 \\
\hline $\begin{array}{l}\text { Namibi } \\
\text { a }\end{array}$ & 4.60 & 4.40 & 4.30 & 4.02 & 3.92 & 3.10 & 4.56 & 5.03 & 4.83 & 4.35 & 4.04 & 5.65 & 5.37 \\
\hline
\end{tabular}




\begin{tabular}{|l|r|r|r|r|r|r|r|r|r|r|r|r|r|}
\hline $\begin{array}{l}\text { South } \\
\text { Africa }\end{array}$ & 2.00 & 3.00 & 4.00 & 4.99 & 5.60 & 6.33 & 6.9 .0 & 7.38 & 7.21 & 5.64 & 3.15 & 2.58 & 4.26 \\
\hline $\begin{array}{l}\text { Swazila } \\
\text { nd }\end{array}$ & 4.00 & 3.93 & 3.90 & 3.86 & 3.90 & 3.79 & 3.88 & 3.35 & 2.94 & 1.98 & 0.25 & -0.51 & -1.15 \\
\hline Zambia & 3.00 & 3.10 & 3.00 & 3.10 & 3.24 & 3.4 & 3.97 & 4.34 & 3.27 & 1.88 & 1.02 & 1.59 & 3.17 \\
\hline $\begin{array}{l}\text { Zimbab } \\
\text { we }\end{array}$ & 3.10 & 3.20 & 3.20 & 3.30 & 3.41 & 3.50 & 3.70 & 3.78 & 2.08 & -0.24 & -1.19 & -0.11 & 2.35 \\
\hline
\end{tabular}

Southern Africa has countries that show very different patterns. The life expectancy at birth in Swaziland is favorable for males in comparison to females. The gender gap is almost I.2 years, with males expecting to live longer on average. Swaziland is one of the two countries in Africa where life expectancy for females is lower than that of males. Although the gender gap for Swaziland was 4 years in favor of females in 1950-1955, this has reversed to 1.2 years in favor of males.

Zimbabwe and Zambia have shown very minor increases in the gender gap and during the height of the AIDS epidemic froml995 to 2010, male exceeded female life expectancy. However, the current gender gap in Zimbabwe is showing the expected patterns where female exceeds male life expectancy by over 2 years. Lesotho shows a moderately stable pattern but has narrowed to almost parity in the recent past.
Malawi shows a unique pattern in Southern Africa. It is the only country which has very low gender differentials. The gap has remained low throughout the period although in the recent past and has been widening until at the peak of the AIDS epidemic during the period 1995-2005.

Botswana and South Africa show similar trends and patterns. They have experienced an increasing gender gap. However, the gap for South Africa was steeper, showing a greater magnitude in the widening of the gender gap. Namibia has consistently experienced a high gender gap throughout the period.

In Table 5, life expectancy gender gaps in West Africa countries during the period 1950-1955 to 20I0-20I5 are presented.

Table 5: Life Expectancy Gender Gap in West Africa Countries during the period 1950-1955 to 2010-2015

\begin{tabular}{|c|c|c|c|c|c|c|c|c|c|c|c|c|c|}
\hline Country & $\begin{array}{c}1950- \\
1955 \\
\end{array}$ & $\begin{array}{c}1955- \\
1960 \\
\end{array}$ & $\begin{array}{c}1960- \\
1965 \\
\end{array}$ & $\begin{array}{c}1965- \\
1970 \\
\end{array}$ & $\begin{array}{c}1970- \\
1975 \\
\end{array}$ & $\begin{array}{c}1975- \\
1980 \\
\end{array}$ & $\begin{array}{c}1980- \\
1985 \\
\end{array}$ & $\begin{array}{c}1985- \\
1990 \\
\end{array}$ & $\begin{array}{c}1990- \\
1995 \\
\end{array}$ & $\begin{array}{c}1995- \\
2000 \\
\end{array}$ & $\begin{array}{c}2000- \\
2005 \\
\end{array}$ & $\begin{array}{c}2005- \\
2010 \\
\end{array}$ & $\begin{array}{c}2010- \\
2015 \\
\end{array}$ \\
\hline Benin & 0.30 & 0.76 & 1.2 & 2.37 & 5.01 & 6.20 & 6.42 & 5.58 & 4.58 & 4.3 & 3.4 & 2.74 & 2.84 \\
\hline $\begin{array}{l}\text { Burkina } \\
\text { Faso }\end{array}$ & 1.98 & 2.04 & 2.16 & 2.23 & 2.38 & 2.44 & 2.36 & 2.23 & 2.36 & 2.93 & 2.06 & 2.46 & 2.60 \\
\hline $\begin{array}{l}\text { Cabo } \\
\text { Verde }\end{array}$ & 2.21 & 2.31 & 2.48 & 2.7 & 2.93 & 3.05 & 3.17 & 3.19 & 3.2 & 3.19 & 3.33 & 3.47 & 3.60 \\
\hline $\begin{array}{l}\text { Côte } \\
\text { d'Ivoire }\end{array}$ & 1.84 & 1.8 & 2.2 & 2.44 & 3.62 & 3.75 & 4.01 & 4.08 & 3.86 & 0.94 & 1.77 & 1.53 & 1.64 \\
\hline Gambia & 2.35 & 2.41 & 2.46 & 2.43 & 2.49 & 2.53 & 2.56 & 2.59 & 2.57 & 2.57 & 2.14 & 2.45 & 2.67 \\
\hline Ghana & 0.49 & 0.46 & 0.83 & 1.10 & 2.47 & 2.48 & 2.34 & 2.03 & 2.32 & 1.62 & 1.6 & 1.71 & 1.91 \\
\hline Guinea & 2.26 & 2.33 & 2.26 & 2.20 & 2.47 & 2.37 & 2.4 & 2.2 & 1.47 & 0.44 & 0.01 & 1.37 & 0.91 \\
\hline $\begin{array}{l}\text { Guinea- } \\
\text { Bissau }\end{array}$ & 2.81 & 3.02 & 3.1 & 3.05 & 3 & 3 & 3.84 & 4.18 & 4.4 & 3.34 & 1.32 & 2.88 & 3.50 \\
\hline Liberia & 5.17 & 4.96 & 4.6 & 3.81 & 3.6 & 3.71 & 3.7 & 4.09 & 4.01 & 1.4 & 1.68 & 1.74 & 1.92 \\
\hline Mali & 1.41 & 1.39 & 1.79 & 1.77 & 1.76 & 1.78 & 1.72 & 0.06 & -0.29 & -0.49 & -0.67 & -0.48 & -0.46 \\
\hline Niger & -0.12 & -0.13 & -0.02 & 0.11 & 0.25 & 0.04 & 0.21 & 0.42 & 0.52 & 0.09 & -0.13 & 0.17 & 1.70 \\
\hline Nigeria & 2.65 & 2.53 & 2.40 & 2.30 & 2.21 & 2.13 & 2.09 & 2.05 & 2.07 & 1.37 & 0.9 & 0.58 & 0.64 \\
\hline Senegal & 1.30 & 1.46 & 1.57 & 1.70 & 1.94 & 2.31 & 2.73 & 3.10 & 3.20 & 3.03 & 3.28 & 2.82 & 3.75 \\
\hline $\begin{array}{l}\text { Sierra } \\
\text { Leone }\end{array}$ & 3.49 & 3.39 & 2.93 & 2.44 & 0.15 & 0.64 & 0.43 & 0.51 & 1.48 & 1.57 & 2.45 & 1.67 & 1.09 \\
\hline Togo & 1.63 & 1.72 & 2.05 & 2.46 & 3.01 & 3.36 & 3.67 & 3.31 & 1.73 & 1.57 & 1.66 & 1.3 & 1.40 \\
\hline
\end{tabular}

In West Africa, the gender gaps are minimal is most countries except for Senegal, Guinea-Bissau and Cabo Verde, where the gender gaps are over 3.5 years. Benin, Burkina Faso and Gambia how very similar patterns and the currently gender gaps are about 2.5 years. In Guinea and Nigeria, there has been a convergence on life expectancy at birth for males and females 
For illustrative purpose, two countries at both ends, that is low and high life expectancies at birth were chosen. In Figure 4, Seychelles that exhibits high life expectancies at birth and Central African Republic which has the lowest are presented. The contrast is used to show how the gender gap differs in low and high mortality settings.

Figure 4: Gender Gaps for Six Selected African Countries

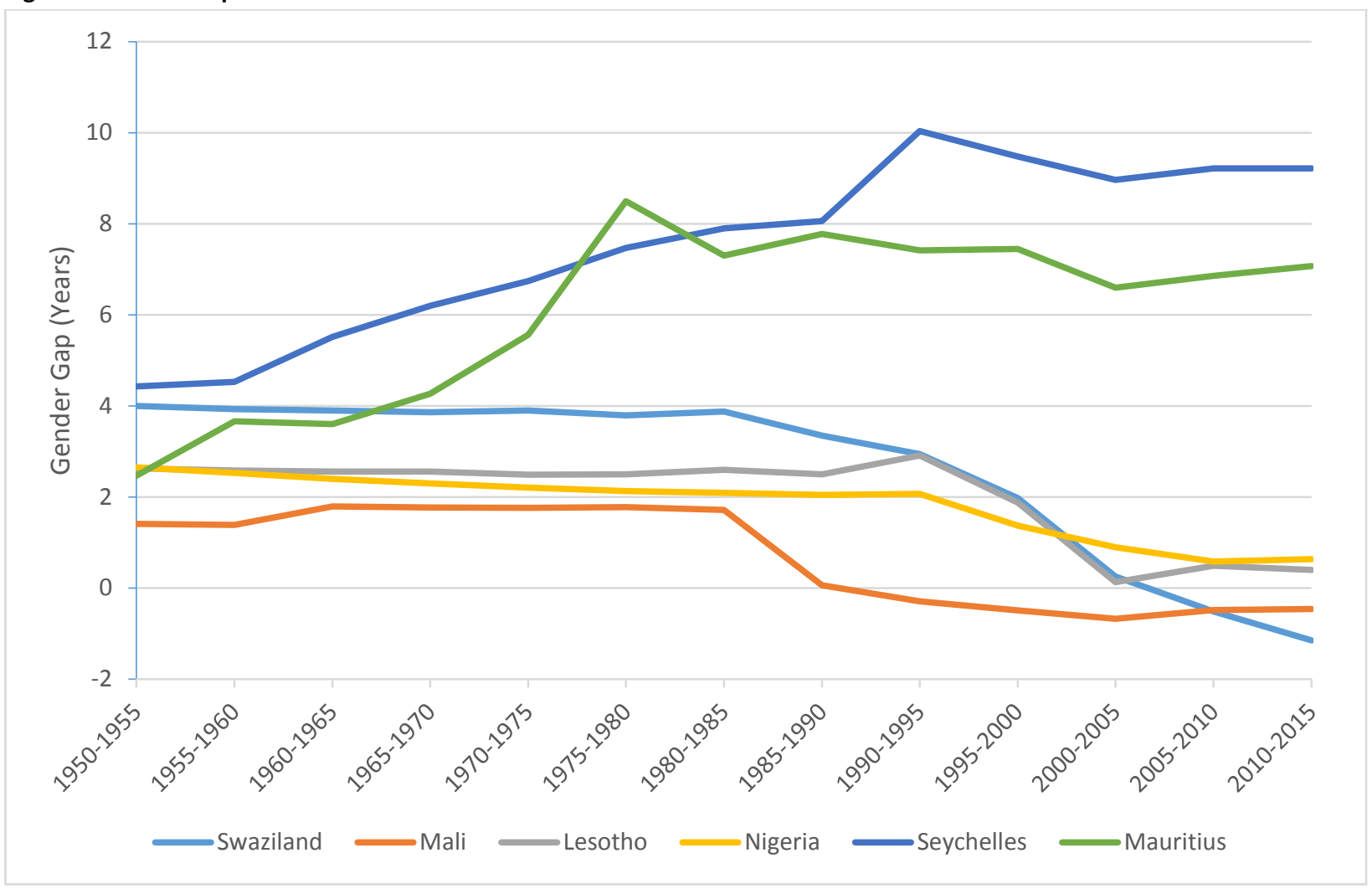

The graph summaries the four patterns that have been observed in Africa. The first group represented by Mauritius and Seychelles have high life expectancies but also large gender gaps. Group I comprises of mainly small islands and those in North Africa whole life expectancy at birth has exceeded 70 years. Lesotho represents the second group being those countries where the gap has been stable but narrowed during the peak of the AIDS epidemic. Group 2 comprises countries mainly in Southern Africa. Nigeria and Mali show those countries where the gender gaps has been low over the period and has narrowed or remained consistently low in recent times. Group 3 countries are mainly in West Africa. The last group comprises of countries where life expectancy at birth for males exceeds that of females. Currently, Swaziland and Mali are the only countries exhibiting this pattern.

\section{Conclusions}

Currently, all countries in Africa have started experiencing an upward trend in life expectancies at birth for both males and females. However, only the small islands (Mayotte, Mauritius, Réunion and Seychelles) and North African countries (Morocco,
Algeria and Tunisia) have high life expectancies that are nearly comparable to other countries in Latin America and Asia. On the contrary, there are still countries on the continent that have life expectancies at birth that are below 50 years and these are characterized by high infant mortality rates. The majority of African countries have life expectancies between 50 and 65 years. The moderate life expectancies being experienced by African countries are a result of high infant mortality rates. As indicated earlier, nine out of the ten countries with the highest infant mortality rates are in Africa.

The gender gap in life expectancy during the period 1955 to 2015 in Africa as a whole has not widened significantly as experienced in other continents. However, there are countries where the gender gap has significantly widened to around 8 years. Although the gender gap in life expectancies in most African countries has not widened as much as implied by the orthogonal regression line used by the United Nations, the trend predicted has been corrected.

In the late 1990s, mortality decline stalled in a number of African countries, especially in Southern Africa which experienced reversals in the gains that 
had been achieved in the health sector and resulted in the downward trend in life expectancy largely because of AIDS mortality. According to Adetunji and Bos (2006) "Nowhere has the decrease in life expectancy been steeper and greater than in Southern Africa, where 40 years of increases in life expectancy were reversed in a period of 10 years". However, these countries in Southern Africa have started to experience a reversal in the downward trend as the HIV prevalence rates have started to go down.

\section{Discussion}

The analyses using longitudinal data on Africa show are regional and country variations. There are countries in Africa that have conformed to the general trend of increased gender gap in life expectancies at birth over time. North Africa and the island countries of Mayotte, Mauritius, Réunion and Seychelles have followed patterns that have been experienced in the Europe and North America. These countries have shown widening gender gaps over the period. The disparities in these countries have been attributed to men's more risky unhealthy behaviors. Males have higher rates of cigarette smoking, heavy drinking, gun use, employment in hazardous occupations, and risk taking in recreation and driving are responsible for males' higher death rate due to lung cancer, accidents, suicide, and homicide (Waldron, 2000; 200I). This is confirmed by the evidence from the Seychelles that show that the large gender gap has been a result of lifestyles risk factors. Alcohol abuse and smoking rates are far higher for males than females in the Seychelles (Muhwava, 2013).

Ttwo countries, Swaziland and Mali currently have women's life expectancies at birth that are less than those of men's, 0.5 and I.2 years, respectively. Evidence from these two countries show that maternal mortality rates are high and this could be contributing to the low life expectancies for females (WHO, 20I4).

The patterns of sex differentials in Southern Africa, especially in the past 20 years shows how HIV \& AIDS has had different impacts on survival of males and females. At the height of the epidemic at around 1995-2000, the life expectancies at birth in most Southern African countries were similar for both males and females. However, with increased availability of ART, the differentials between males and females have started to emerge and have been attributed to delay in care-seeking among men and gender differences in adherence and retention in ARV treatment programs (Bor et al, 20I5).

\section{References}

Adetunji, J \& Bos, E.R (2006). "Levels and trends in mortality in sub-Saharan Africa. An overview" in D.T. Jamison, R.G Feachem, M.W. Makgoba, et al (eds). Disease and mortality in sub-Saharan Africa (2nd ed). Washington DC: World Bank.

Barford A, Dorling D, Smith G and Shaw M. (2006) Life expectancy: women now on top everywhere. BMJ. 2006,332 (7545):808.

Bor J, Rosen S, Chimbindi N, Haber N, Herbst K, Mutevedzi T, et al. (2015) Mass HIV Treatment and Sex Disparities in Life Expectancy: Demographic Surveillance in Rural South Africa. PLoS Med I 2(II)

Coale and Demeny (1966). Regional Model Life Tables and Stable Population. Princeton University Press. Princeton. New Jersey.

Muhwava W. (2015) Social Determinants of Health and Inequalities in Seychelles: Evidence and Implications. Ministry of Health (Seychelles) and WHO.

Nathanson, Constance. 1984. "Sex Differences in Mortality." Annual Review of Sociology 10:191213.

Pampel, F. (2002). "Cigarette Use and the Narrowing Sex Differential in Mortality." Population and Development Review 28:77-104.

Sowder W (1954). Why Is the Sex Difference in Mortality Increasing? Public Health Reports (18961970) Vol. 69, No. 9 (Sep., 1954), pp. 860-864

UNICEF (2014) Levels \& Trends in Child Mortality. Report 2014. Estimates Developed by the UN Inter-agency Group for Child Mortality Estimation.

UNDESA (1988) Sex differentials in survivorship in the developing world: levels, regional patterns and demographic determinants. Population Bulletin No. 25:5I-64. United Nations. New York.

United Nations (1982). Model Life Tables for Developing Countries. United Nations. New York

WHO (20I4): Global maternal newborn, child and adolescent health policy indicator database based on key informant surveys in 2009-10, 20II \& 2013-14

Waldron I. (2000): "Trends in gender differences in mortality: relationships to changing gender differences in behaviour and other causal factors", in: Annandale E., Hunt K. (Ed.): Gender inequalities in health, Buckingham: Open University: |50-|8|.

Wiehl, D. G. (1938). Sex differences in mortality in the United States. The Milbank Memorial Fund Quarterly, I45-I55. 
' Chief of Population and Youth Section, Economic Commission for Africa, Addis Ababa, Ethiopia: wmuhawava@uneca.org.

${ }^{2}$ Population Affairs Officer, Economic Commission for Africa, Addis Ababa, Ethiopia:grutaremwa@uneca.org 